\title{
SOCIAL WORK: training, professional work, and modern theoretical trends
}

This issue of Katalysis, with the theme Social Work: training, professional work, and modern theoretical trends, is released in a particularly troubled time in Brazil. It is a moment where the incumbent government adopts a 'policy of death,' or a 'necropolicy' that explicitly determines who can or cannot live. It is crucial to resist to this kind of force, fighting it daily on the 'shop floor' or in academic spaces, by producing information that is socially acknowledged from the emancipation and liberation of those who live by selling their workforce. Societal transformations, at this moment of capitalist accumulation, demand radicality to guarantee a meaningful life, which is the outcome of collective construction of another world, where there are no longer exploiters or the exploited.

The presentism and obscurantism approaches, as expressions of modern trends, find in this issue of Katalysis a blunt and concrete response. The journal's theme discusses the worsening of the process of dehumanization and life degradation, reflecting on how societal transformations, both in form and content, affect social workers' training and professional work.

Based on a conception of profession that does not dissociate work and vocational training, the Brazilian social work is a consolidated field of knowledge production. The articles published in this issue assert for investment and strengthening of research in the field, as well as reaffirming the ethical-political and theoreticalmethodological direction, committed to the break with conservatism and the demystification of social relations that engender the current pattern of capitalist accumulation. The ontology of social being based on Marx's work and tradition is the guiding thread that unifies and gives robustness to the authors' intellectual contribution.

This issue is organized in three sessions, presenting fifteen articles and a review, produced by both young and experienced researchers, women and men from different regions of the country, with texts written in Portuguese and one in Spanish. Individually and as a group, these articles show a commitment to science, facing the daily immediacy and the contempt for a critical reason.

The first article in the section 'Thematic Space,' is In times of dehumanization: the emergence of ontological criticism in the educational complex, by Patricia Laura Torrigli, Vidalcir Ortigara, and Astrid Baecker Avila. The authors criticize the conception of education in the capitalist sociability and the devaluation of the research and human development. They advocate the need for a new form of knowledge that considers totality, pointing out the prominence of the ontology of the social being.

In their work The production of knowledge and the political ethical project of social work, Sandra Lourenço de Andrade Fortuna and Olegna de Souza Guedes consider knowledge production as one expression of human activity. According to the authors, it is necessary to establish connections between research on social work and the social meaning of the profession.

Carolina González Laurino considers the current times of irrationalism in the work The paradoxes of reason in tasks of university research and teaching, studying the changes in student profile and the challenges of overcoming the paradoxes related to research and teaching. The research focuses on the academic program in social work at the Universidad de la República, in Montevideo, Uruguay.

\section{(@) $\mathbb{Q} \otimes$}

(C) The Author(s). 2020 Open Access This article is distributed under the terms of the Creative Commons Attribution-NonCommercial 4.0 International License (http://creativecommons.org/licenses/by-nc/4.0/), which permits use, distribution, and reproduction in any medium, since it's for non-commercial purposes, and provided you give appropriate credit to the original author(s) and the source, provide a link to the Creative Commons license, and indicate if changes were made. 
The article by Viviane Medeiros dos Santos, Societal transformations: repercussions on social work, is based on the literature about the profession in Brazil and analyzes the determinations of modern capitalism. The author studies the process of precariousness in both professional training and work, highlighting the impact of Brazil's labor and social security counter-reforms for the working class as a whole and particularly for social workers.

The work by Rayane Noronha Oliveira and Tássia Monte Santos, The relevance of research for Social Work: Permanent achievements and challenges of Curriculum Guidelines, reaffirms the historical achievement of the curriculum guidelines for the education of social workers, approved by the Brazilian Association of Social Work Teaching and Research (ABESS), on November 8, 1996. For the authors, "the profession of social worker needs to be back in the research agenda of the field, i.e., be the object of study by the research community."

The work by Priscila Fernanda Gonçalves Cardoso, Terezinha de Fátima Rodrigues, and Heloise Helena Pereira Nunes, Social work and ongoing training: possibilities of overcoming alienating routines, discusses the progress made by social workers when approving the National Policy of Permanent Education of the Federal and Regional Councils of Social Work (CFESS-CRESS) (2012). The authors resume the principles and point out challenges and opportunities in the construction of democratic spaces of training after undergraduate studies.

In the article Social Work and Scientific Research: A Vital Relationship for Professional Education, Luciene Araújo, Gilcélia Batista de Góis, Gleidiane Almeida de Freitas, and Mariana Gleicy de Oliveira Silva Sousa debate the locus of the scientific research in vocational training. The authors highlight its importance as a transformative practice that allows demystifying and denaturalizing daily life.

Claudia Neves da Silva and Patrícia Palmeira Gonçalves present the work Distance Learning and Social Workers' Professional Education: Elements for Debate, debating the challenges and damaging consequences of distance learning for the profession and society as a whole. The authors stress that the objective of their analysis is not the workers or students engaged in distance learning. They analyze the predominance of mass education and its standardization, which does not follow the framework established by the ABEPSS curriculum guidelines, as well as not fulfilling the requirement of connecting teaching, research, and extension, essential for the quality of vocational training.

In the article Marxian analysis of quota policy in Brazilian public higher education, Cassia Engres Mocelin shows to be in tune with the necessary democratization of access to the public university. The author asks, "to what extent does the policy of social and ethnic-racial quotas constitute processes of resistance to fair distribution and equal bourgeois rights?" Her references are the federal higher education institutions (IFES), and she analyzes the process of the social formation of the state in Brazil, based on the connections between class and race. After, the author reflects on the policies of social and ethnic-racial quotas, supported by the categories equal rights and fair distribution.

Concluding the ten articles of the Thematic Space, is the work by Daniel Pericles Arruda, Hip-Hop culture and social work: the art to overcome the social invisibility of peripheral youth. The author argues that "art is a way of life, a group experience that builds identities; It is also a form of political struggle to face social inequalities, violence, and indifference," which are issues experienced by disadvantaged youth in their daily life.

The journal's space dedicated to general topics presents the work by Rodrigo Castelo, Gramsci and the critique of political economy: studies on the determined market. For the author, "the critique of political economy has considerable weight, which is not always recognized by Gramsci's work commentators." He invites readers to re-evaluate the weight of studies on economics within Gramsci's theory.

The article The labor counter-reform and the precariousness of labor relations in Brazil, by Saionara da Silva Passos and Márcio Lupatin, analyzes the first year of Brazilian Law 13467/2017 providing on labor reform. The authors demonstrate that instead of achieving the declared goals, the legislation resulted in a growth in unemployment rates, informality, and limited access to labor justice, which evidence the fulfillment of requirements of the general law of capitalist accumulation.

Maria Augusta Tavares calls for the unification of the working class in her work Aging and Work in the Capitalist Society. For the author, it is necessary to unveil the capitalist plot and analyze "the condition of the aging worker, under the determinations of a pattern of development [neoliberalism] in which internal contradictions undermine their [the worker] way of being."

In the article, A company managing the university hospital: from resistance to corporate management, Tânia Regina Kruger, Bruna Veiga de Moraes, and Cristiane Borghezan Sobieranski present the process of resistance that occurred at the Federal University of Santa Catarina, Brazil, against practices characterized by state managerialism. After three years of implementation of such practices, particularly the private management of the public university hospital, the quality of the services declined. According to the authors, "the quality of the teaching hospital is threatened, the services are being restricted based on purely managerial justifications, and the workers are in poorer working conditions." Counter-reform measures in the health area, similarly to that evidenced in the field labor rights (shown before) express the voracity of capital in the "assault" on the public fund. 
Finally, the article by Daniel Figueiredo de Almeida Alves, Oziris Simões, Leonardo Carnut, and Áquilas Mendes, Psychiatric reform and Brazilian dependence: between the archaic and the modern, presents the "permanence of asylum (archaic) characteristics, combined with substitutive services (modern)" in mental health institutions. The authors studied data on mental health in the city of São Paulo for the years 2008 to 2017, concluding that "the Brazilian Psychiatric Reform will not break obstacles [...] if it does not resume a radical perspective of health that faces the alienation and fetish of the 'Protective State,' presenting an anti-capitalist and emancipatory alternative."

The review written by Sabrina Areco for this issue presents the work The Young Gramsci: Five Years That Seem Like Centuries 1914-1919 (2014), by Leonardo Rapone, edited by Editora Contraponto and Fundação Astrogildo Pereira. The work by Rapone discusses the life and production of Antonio Gramsci (1891-1937), studying the documents Gramsci published in the Italian Socialist Press between 1914 and 1919. The thought-provoking review invites us to understand the social education in Italy in that period, as well as to know the particularities of Sardinian author's biography.

This issue of Katalysis is the first of a new year. I hope that the commitment to theoretic-methodological rigor and the revolutionary ethical-political direction expressed in the articles published here fertilize hearts and minds by strengthening the Brazilian social workers' professional training and work.

Esther Luíza de Souza Lemos Toledo (PR), December 10, 2019.

\section{Esther Luíza de Souza Lemos}

https://orcid.org/0000-0002-7154-1475

estherlemos@gmail.com

$\mathrm{PhD}$ in Social Work from the Federal University of Rio de Janeiro (UFRJ), Adjunct Professor at the Western Paraná State University (UNIOESTE), and President of the Brazilian Association of Social Work Teaching and Research (ABEPSS) (mandate 2019-2020).

\section{UNIOESTE}

Graduate Program in Social Work

Rua da Faculdade, 645 - Jardim Santa Maria

Toledo - Paraná - Brasil

CEP: 85.903-250 